\title{
Incidence of the circadian rhythm of the excretion pattern on acetate absorption and metabolism in the rabbit hind-gut
}

\author{
M. Vernay
}

Laboratoire de physiologie de la digestion et de la nutrition, Université Paul Sabatier, 2, rue F-Magendie, 31400 Toulouse, France

(received 25-3-1988, accepted 9-1-1989)

Summary - Acetate absorption in the hind-gut of anaesthetized rabbits was evaluated by measuring variations in the concentration of acetate in caecocolonic loops and in arterial and venous plasma. In vivo metabolism in gut and liver tissues was studied using $[1-14 \mathrm{C}]$ acetate. Interrelations between acetate absorption and metabolism and both phases of the excretory cycle of the rabbit were examined.

The disappearance rate from the caecocolonic loop was quantitatively significant. The gut tissue metabolized acetate, and the intensity of utilization varied with the segment studied; the distal position of the large intestine showed by far the highest uptake of short-chain fatty acids $\left(\mathrm{SCFA}_{\mathrm{s}}\right.$ ). In addition, acetate absorption, like its metabolism in the hind-gut and liver tissues, differed in intensity according to the phase of the excretory cycle, i.e., both mechanisms were enhanced during hard faeces production.

Radioactivity was found in free amino acids, organic acids and sugars. Irrespective of the location in the gut and the excretion pattern, acetate was rapidly converted into glutamate and aspartate; these nutrients were subsequently diverted towards either oxidative metabolism or biosyntheses (non essential free amino acids, proteins).

rabbit - hind-gut - excretory cycle — acetate behaviour

Résumé - Incidence du rythme circadien de l'excrétion fécale sur l'absorption et le métabolisme de l'acétate dans le gros intestin du lapin. Sur des lapins anesthésiés et porteurs d'anses cæco-coliques, il apparaît que, quelle que soit la phase d'émission fécale de l'animal fèces molles ou fèces dures - la paroi du gros intestin ne perd pas sa capacité d'absorption pour l'acétate lorsqu'on s'éloigne de la jonction cæco-colique comme les variations des concentrations dans le plasma efférent pourraient le suggérer. Au cours de son passage dans les tissus digestifs et hépatique, une partie non négligeable et variable de l'acétate est captée et métabolisée. L'utilisation d'acétate marqué, puis la recherche du radiocarbone dans les acides aminés, les acides organiques et les glucides, confirment que l'activité métabolique du cólon est nettement supérieure à celle du cæcum. L'incorporation du radiocarbone dans les différentes molécules biochimiques appartenant au métabolisme intermediaire cellulaire montre que "ce déchet" du métabolisme bactérien est aussi bien utilisé chez le lapin que chez les ruminants. L'acétate est largement converti en acides glutamique et aspartique, ultérieurement ces composés pourront être 
orientés soit vers le métabolisme oxydatif, après retour au cycle tricarboxylique, soit vers des synthèses (acides aminés, protéines). Aux niveaux digestif et hépatique, l'absorption et le métabolisme de l'acétate sont toujours plus intenses lorsque le lapin élimine des fèces dures.

lapin - gros intestin - excrétion fécale - acétate

\section{Introduction}

It is well known that rabbits in a circadian rhythm produce soft and hard faeces which are distinctly different in size and chemical composition (Henning and Hird, 1972a; Vernay and Raynaud, 1975; Hörnicke and Björnhag, 1980; Vernay, 1987a). A large proportion of the energy requirement $(30-40 \%)$ is derived from the catabolism of short-chain fatty acids $\left(\mathrm{SCFA}_{\mathrm{s}}\right)$ : acetate, propionate, and butyrate formed by microbial fermentation of the fodder in the hind-gut; nearly half of the energy supplied is due to butyrate (Hoover and Heitmann, 1972; Parker, 1976; Marty and Vernay, 1984). The rabbit large intestine epithelium metabolizes the SCFA; it is most active on butyrate, less active on propionate, and least active on acetate (Marty and Vernay, 1984), and the intensity of this metabolism varies with the location in the gut (Henning and Hird, 1972b, c; Marty and Vernay, 1984; Vernay, 1985, 1987b). In addition, propionate and butyrate utilization differs in intensity according to the phase of the excretory cycle (Vernay and Marty, 1984; Vernay, 1985, 1987c). During hard-phase excretion the absorptive processes, as well as complete oxidation of propionate and butyrate, are enhanced in the proximal colon and to a lesser degree in the distal colon, yielding energy for metabolic processes; during soft faeces production these bacterial metabolites are also oxidized to carbon dioxide but are a better source of free amino acids (Vernay et al., 1984, Vernay, 1987d).
Until now, little or no information has been reported concerning the incidence of the excretion pattern (soft-phase and hard-phase) on acetate behaviour. The purpose of the present investigation was to study the relations between acetate absorption and metabolism in the hind-gut and the excretion pattern of rabbits.

\section{Materials and Methods}

\section{Animals}

A total of 20 male domestic rabbits (Oryctolagus cuniculus) weighing about $2.5 \mathrm{~kg}$ were provided with oats, lucerne, and water ad libitum.

The experiments were carried out either between 04.00 and $07.00 \mathrm{~h}$ (period of soft faeces formation) or between 10.00 and $18.00 \mathrm{~h}$ (period of hard faeces formation).

\section{Experimental procedure}

The rabbits were anaesthetized by administration of a pentobarbital solution $(20 \mathrm{mg} / \mathrm{kg}$ ) through the marginal vein of the ear. After laparotomy the large intestine was removed and three approximately equivalent (wet wt; serosal area) loops were made from the caecum (median area), the proximal colon (single-fold haustrated), and the distal colon. For anatomical details see Snipes et al. (1982). A polythene catheter ( $P E$ 90) was inserted into one of the small caecocolonic veins draining each loop, and care was taken to ensure that the blood circulation was not damaged. A carotid artery was exposed and cannulated (PE 190).

The loops were washed out with Ringer's solution at $38^{\circ} \mathrm{C}$ and were then filled with $5 \mathrm{ml}$ of the experimental solution. This solution contained $(\mathrm{mM}): 159 \mathrm{Na}, 17 \mathrm{~K}, 0.7 \mathrm{Ca}, 4.3 \mathrm{Mg}$, 
$83 \mathrm{Cl}, 26 \mathrm{HCO}_{3}, 19 \mathrm{PO}_{4}, 37$ acetate, 10 propionate, 15 butyrate had a $\mathrm{pH}$ of 7.1 at $38^{\circ} \mathrm{C}$ and an osmolality of 330 mosmol $/ \mathrm{kg}$.

Two $\mathrm{g}$ of polyethylene glycol (a non absorbable marker substance) // (PEG) was added to the test solution. Just before the experiment, then every $5 \mathrm{~min}$ for $20 \mathrm{~min}, 0.6-\mathrm{ml}$ blood samples were simultaneously collected through the catheters in a heparinized beaker. After each collection, the volume of blood withdrawn was replaced (via the marginal vein of the ear) with physiological saline solution and the catheters were filled with a solution of heparin (40 IU/ml physiological saline). At the end of incubation, blood samples were taken from the portal and hepatic veins and the animal was killed with an overdose of pentobarbital; the loops were emptied and the samples were immediately placed on ice. The caecocolonic loops, together with a portion of each lobe of the liver, were resected and weighed. The serosal area of the loop was evaluated by planimetry.

Two groups of experiments were performed. The first series was undertaken to determine the influence of the mode of excretion on acetate absorption in the caecocolon. Fourteen rabbits were used with two consecutive 20-min test periods for each subject. Seven of the 14 rabbits were in soft-phase; the remainder were in hard-phase. In a second series of experiments $30 \mu \mathrm{Ci}$ of $[1-14 \mathrm{C}]$ acetate were added to the test solution. Of the 6 rabbits used for these metabolism studies, 3 were in softphase and the others in hard-phase. The total duration of the test was $20 \mathrm{~min}$ for each subject.

\section{Analytical methods}

Preparation of the caecocolonic and hepatic tissues used in this study has been described elsewhere (Marty and Vernay, 1984; Vernay, $1987 \mathrm{c}, \mathrm{d})$ and is briefly summarized below. The various tissues were homogenized in ice-cold water with an Ultra-Turrax electric blender. The homogenates were extracted in boiling water under low pressure, which permitted the elimination of the volatile fraction. The insoluble fraction was then removed by centrifugation ( 30 $\min , 10,000 \mathrm{~g}$ ). In order to obtain an adequate aqueous phase the lipid-soluble substances had to be eliminated with chloroform (3 extractions vol/vol) in a separation funnel. For the plasma samples, protein precipitation with sulphosalicylic acid $(15 \mathrm{~g} / \mathrm{l})$ preceded the chloroform extraction procedure. The aqueous fraction was then recovered and concentrated in a Rotavapor (Büchi). To detect radioactivity, the method developed by Schurmann (1969) and Lavergne et al. (1979), which separates free amino acids, organic acids, and sugars on the same autoradiographs, was appropriately adapted. An aliquot of this liquor was first subjected to electrophoresis (2 100 V, $40 \mathrm{~mA}, 1$ h) in an acid medium : formic acid / acetic acid / water (17:57:926, vol/vol) at $\mathrm{pH} 2$. After drying, double development ascendant chromatography was used in butan-2-ol/formic acid/water $(6: 1: 2, \mathrm{vol} / \mathrm{vol})$. The autoradiographs were obtained by leaving the electrophoresis paper in prolonged contact with the photographic plates (Kodak Kodirex). The radioactive spots were then eluted and the ${ }^{14} \mathrm{C}$ activity was determined in a liquid scintillation counter (Packard $460 \mathrm{C}$ ). The variations in the labelling balance of the volatile, insoluble (proteins), lipid-soluble, and aqueous fractions are of interest, but previous works (Marty and Vernay, 1984; Vernay and Marty, 1984; Vernay, 1985. $1987 \mathrm{~b}, \mathrm{c})$ have shown the relevance of studying the distribution of radioactive carbon in free amino acids, organic acids, and sugars. Consequently, for the present investigation only the aqueous fraction was considered. Blood acetate was determined after ethanol extraction as described by Rémésy and Demigné (1974), while the acetate of the test caecocolonic solutions was measured after acidification of 1 $\mathrm{ml}$ of the sample with $100 \mu \mathrm{l}$ of formic acid. The acetate was subsequently assayed by gas-liquid chromatography (Intersmat IGC 120 DSL). The polyethylene glycol (PEG) concentration was determined according to the procedure described by Hyden (1956).

\section{Calculations}

The formula used in calculating net acetate disappearance in the caecocolonic loop was :

Net acetate disappearance $(\mu \mathrm{mol})=C_{0} V_{0}-$ $c_{t} V_{0}\left(\mathrm{PEG}_{0} / \mathrm{PEG}_{t}\right)$

where $V_{0}$ is the volume of fluid in the loops at the beginning of the experiment and $C_{0}$ and $C_{t}$ are the acetate concentrations $(\mu \mathrm{mol} / \mathrm{l})$ at the beginning and end of the experiment. Acetate disappearance and ${ }^{14} \mathrm{C}$ incorporation into metabolites were expressed per gram of wet tissue; the mean weights $(g)$ of the caecal, proximal, and distal colonic loops were $6.3 \pm$ $1.9,6.5 \pm 1.2$, and $5.1 \pm 1.3$, respectively.

It was assumed that the portal vein and the hepatic artery represented $70 \%$ and $30 \%$, 
respectively, of the hepatic blood flow (Greenway and Stark, 1971; Bergman and Wolff, 1971; Rémésy and Demigné, 1982). Afferent plasma concentrations were thus 0.7 (portal vein) +0.3 (arterial vein), the hepatic balance being the difference between the hepatic vein and the afferent plasma. The proportion of hepatic uptake was calculated with the ratio hepatic balance/afferent.

The results are presented as means with their standard errors. Differences were evaluated statistically using paired or unpaired Student's $t$-test, as appropriate.

\section{Results}

Disappearance of acetate in caecocolonic loops

The concentration of acetate used in the present work was $37 \pm 0.5 \mathrm{mM}$, which is regarded as physiological (Vernay and Raynaud, 1975; Leng, 1978; Vernay, 1987a). Twenty min after introduction of the test solution the rate of acetate disappearance from the hind-gut was always high (Table I), but it was invariably greater during hard-phase than during soft-phase; at the end of incubation, $33 \%$ (soft-phase) to $45 \%$ (hard-phase) of the acetate inserted into the loops had disappeared. In addition, during hard- phase, the disappearance rate was consistently higher in the colon than in the caecum $(P<0.001)$.

\section{Arterial and venous plasma concentration of acetate}

Irrespective of the mode of faecal excretion, the level of acetate in the arterial plasma was remarkably constant; the mean value was $2220 \pm 230 \mu \mathrm{M}$, which represented $89 \%$ of the total SCFA $_{5}$. Differences in the concentrations of acetate in the arterial and venous plasma were always greater in the caecum than in the colon (Table II). Although the net disappearance of acetate in the caecocolonic loops increased during the hard-phase, there was little acetate enrichment in the efferent colonic plasma.

During the soft-phase the liver tissue removed about $18 \%$ of the acetate reaching it; meanwhile, the hepatic balance for the hard-phase was $35 \%(P$ $<0.001$ ). Thus there was no obvious variation of the acetate concentrations in the hepatic vein in relation to the excretion pattern. The differences between the venous and arterial metabolite concentrations allow interesting comparisons of metabolite fluxes in identical physiological

Table I. Influence of the mode of excretion, soft faeces or hard faeces, on the disappearance $(\mu \mathrm{mol} / \mathrm{g}$ wet $w \mathrm{t} / 20 \mathrm{~min}$ ) of acetate from the caecocolonic loops.

\begin{tabular}{lll}
\hline \multirow{2}{*}{ Sites } & Faeces & \\
\cline { 2 - 3 } & $\begin{array}{l}\text { Soft } \\
(17)\end{array}$ & $\begin{array}{l}\text { Hard } \\
(17)\end{array}$ \\
\hline Cæcum & $5.3 \pm 0.3^{*}$ & $7.9 \pm 0.2$ \\
Proximal colon & $6.2 \pm 0.2^{*}$ & $12.3 \pm 1.2$ \\
Distal colon & $6.0 \pm 0.9^{*}$ & $10.9 \pm 1.0$ \\
\hline
\end{tabular}

Mean \pm SE. ( ), number of observations.

Student's $t$-test, comparison soft/hard faeces. Significance, $" P<0.001$. 
Table II. Influence of the mode of excretion, soft faeces or hard faeces, on acetate concentrations $(\mu \mathrm{mol} / 100 \mathrm{ml})$ in arterial and venous plasma of the rabbit.

\begin{tabular}{|c|c|c|}
\hline \multirow[t]{2}{*}{ Plasma } & \multicolumn{2}{|l|}{ Faeces } \\
\hline & $\begin{array}{l}\text { Soft } \\
(17)\end{array}$ & $\begin{array}{l}\text { Hard } \\
\text { (17) }\end{array}$ \\
\hline Arterial & $230 \pm 21$ & $208 \pm 30$ \\
\hline Cæcal & $460 * \pm 46$ & $728 * \pm 104$ \\
\hline Proximal colonic & $345^{*} \pm 23$ & $237 \pm 15$ \\
\hline Distal colonic & $276 \pm 32$ & $260 \pm 24$ \\
\hline Portal & $312^{*} \pm 54$ & $416 * \pm 46$ \\
\hline Afferent hepatic & $308 \pm 42$ & $342 \pm 38$ \\
\hline Efferent hepatic & $238 * * \pm 30$ & $230^{*} \pm 40$ \\
\hline
\end{tabular}

Mean \pm SE. ( ), number of observations.

- For calculations of afferent hepatic plasma see Materials and Methods.

Student's $t$-test, comparison arterial/venous plasma. Significance, ${ }^{*} P<0.001 ; * * P<0.01$.

situations. However, comparisons of metabolite fluxes in different situations would also necessitate measurement of blood flow. To our knowledge, there is no reference concerning possible blood flow variations in relation to the phase of the excretory cycle of the rabbit. Nevertheless, it has been shown for ruminants (Dobson and Phillipson, 1956; Bensadoun et al., 1962; Sellers, 1965), dogs (Kvietys and Granger, 1981), and rats (Demigné and Rémésy, 1985) that an increase in the SCFA $_{\mathrm{S}}$ level in the mesenteric circulation enhances blood flow. If this is the case for the rabbit, the evaluation of the hepatic uptake that we propose was underestimated for rabbits in hard-phase.

${ }^{14} \mathrm{C}$ incorporation into metabolites isolated from the aqueous fraction

Twenty min after introduction of $\left[1-{ }^{14} \mathrm{C}\right]$ acetate into the gut loops, radioactivity was found to be present in the different samples (Table III). On a per gram wet hind-gut tissue basis, the ${ }^{14} \mathrm{C}$ content significantly augmented as the distance from the caecocolonic junction increased $(P<0.001)$; the level of radioactivity in the proximal and distal colon was 11 and 20 times more, respectively, than in the caecum. In addition, total ${ }^{14} \mathrm{C}$ incorporation was always higher during hard-phase than during soft-phase: approximately twice more in the caecum, distal colon, and liver, and 5 times more in the proximal colon $(P<0.001)$. Compared with the quantities of $\left[1-{ }^{14} \mathrm{C}\right]$ acetate that disappeared, the amount of radioactivity recovered in the aqueous fraction of the gut tissues ranged between $1 \%$ (softphase) and $2 \%$ (hard-phase) for the caecum, between $5 \%$ and $21 \%$ for the proximal colon, and between $14 \%$ and $24 \%$ for the distal colon.

Examination of Table III shows that radioactivity was always detected in a number of metabolites, i.e., in free amino acids, organic acids, and sugars. It is interesting that, irrespective of differences in the ${ }^{14} \mathrm{C}$ content of the caecocolonic tissues, the labelling balance of these three biochemical metabolites was 


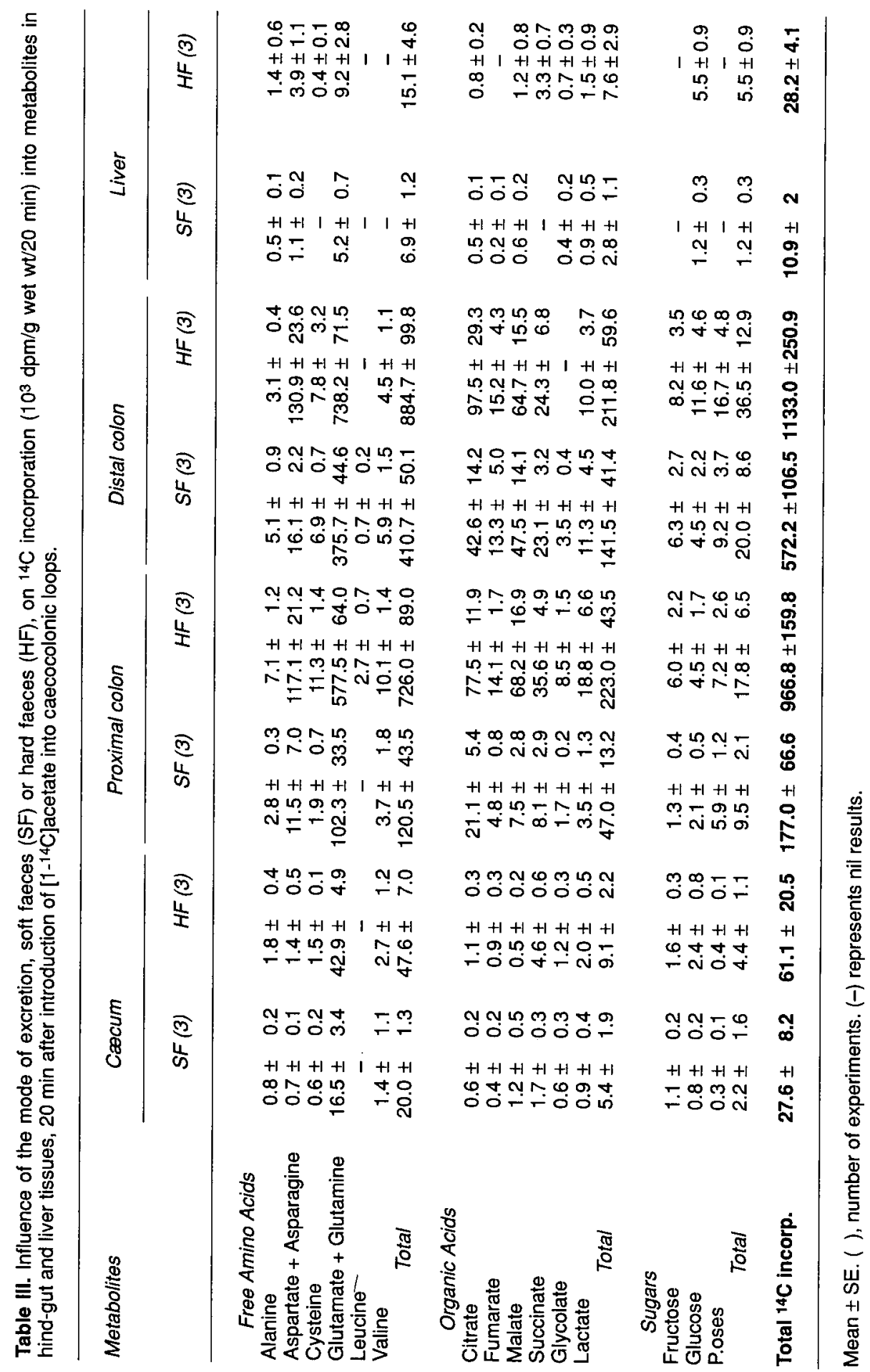


remarkably constant. Radioactivity was accounted for mainly by free amino acids $(75 \%)$, but also by organic acids $(22 \%)$ and sugars $(4 \%)$. Of the ${ }^{14} \mathrm{C}$ content in free amino acids, $84 \%$ was regularly detected in glutamate and $12 \%$ in aspartate. In the case of the labelled organic acids, $90 \%$ of the radioactivity was found in the tricarboxylic acid (TCA) cycle acids.

For liver tissue, the percentage of radioactivity recovered in free amino acids slightly decreased with respect to gut wall $(56 \%)$, while the incorporation of sugars increased (17\%); likewise, the incorporation of ${ }^{14} \mathrm{C}$ into glutamate and TCA cycle acids was not as great : $65 \%$ for the first metabolite and $63 \%$ for the second.

Most of the labelled molecules present in the digestive walls were detectable in the corresponding venous plasma. The total radioactivity measured in the aqueous fraction ranged between 4.7 (soft-phase) and 5.8 (hard-phase) $\times 10^{3}$ $\mathrm{dpm} / \mathrm{ml}$; in addition, $25 \%$ of the total ${ }^{14} \mathrm{C}$ was recovered in the free amino acids (alanine, aspartate, glutamate), $22 \%$ in the organic acids (citrate, lactate), and the remainder $(53 \%)$ in glucose. The radioactivity found in arterial plasma ranged between 1.6 (soft-phase) and 3.9 (hardphase) $\times 10^{3} \mathrm{dpm} / \mathrm{ml}$, and the radiocarbon was only found in citrate, lactate and glucose.

\section{Discussion}

Whatever the mode of excretion (soft or hard faeces), the rate of rabbit hind-gut acetate absorption did not diminish with increasing distance from the caecocolonic junction, as variations in the venous blood concentrations might suggest. In rabbits (Henning and Hird, 1972b,c; McMillan et al., 1975; Marty and Vernay, 1984) as in rats (Rémésy and Demigné, 1976; Rémésy et al., 1980), pigs (Argenzio and Southworth, 1974), or ruminants (Cook and Miller, 1965; Bergman and Wolff, 1971; Pethick et al., 1981), the metabolic activity of the digestive epithelium explains the variations of SCFA levels in venous blood. The low concentrations of acetate in the colonic bloodstream and the labelling of free amino acids, organic acids, and sugars in the tissues implies that its catabolism by the colonocytes was extremely efficient and that the extent of the phenomenon depended on the excretory cycle.

The pattern of the distribution of ${ }^{14} \mathrm{C}$ into different metabolites shows that irrespective of the tissue and the excretory cycle, acetate followed the same pathway; this is not the case for propionate (Vernay, 1987b) or butyrate (Vernay, 1987c). The initial enzyme step in the mitochondrial utilization of acetate was the formation of acetyl-CoA via the acetyl-CoA synthetase (EC 6.2.1.1.) reaction. Thus the acetyl-CoA was rapidly introduced into the TCA cycle, partly oxidized to $\mathrm{CO}_{2}$, and largely converted into ketoglutarate and oxaloacetate, precursors of glutamate and aspartate, respectively. We never found such an accumulation in earlier work with labelled propionate (Vernay, 1987b) or butyrate (Vernay, 1987c). In the rabbit hind-gut, metabolites were probably exchanged between the mucosa and the microflora of the crypts; however, with in vitro studies of the endoluminal flora it appeared that $\left[{ }^{14} \mathrm{C}\right]$ acetate (unpublished results), like $\left[{ }^{14} \mathrm{C}\right]$ butyrate (Vernay and Marty, 1984), was not catabolized after addition to the culture medium. Thus it seems reasonable to ascribe the role of principal users of acetate to colonocytes. On the basis of the present in vivo experiments, glutamate and aspartate appear to be 
quantitatively important intermediates in acetate oxidation; subsequently, the latter nutrients would be slowly oxidized into carbon dioxide or utilized in numerous syntheses (Fig. 1). A kinetic study involving a longer absorption time might confirm this hypothesis. The present finding is in line with that of Henning and Hird (1972c) studying the rabbit colon; in in vitro experiments with labelled acetate applied to the mucosal surface of everted colonic sacs, they found that almost all the radioactivity lost from the incubation fluids was taken up by the wall, and that little $\mathrm{CO}_{2}$ was released during the 60 -min incubation. In addition, $35-67 \%$ of the initial radioactivity was recovered in the water-soluble fraction of the colonic tissue. Substantial labelling of glutamate and aspartate was also reported by Holdsworth et al. (1964) and by Mayfield et al. (1966) in in vitro incubations of various tissue homogenates of sheep with [1-14 C]acetate. In addition, Bergman and Wolff (1971) and Pethick et al. (1981) estimated that $30 \%$ of the absorbed acetate was directly utilized by the rumen epithelium of sheep. The amount of label recovered in the aqueous fraction of the colonic tissue suggests that the large intestine wall of rabbits transforms acetate as efficiently as that of ruminants. As with propionate and butyrate, acetate disappearance and consumption by the gut wall were intensified in the proximal colon and, to a lesser degree, in the distal colon when the animal eliminated hard faeces. In fact, in the course of hard faeces production, during which plasma levels of aldosterone (Clauss and Hörnicke, 1979a,b; Vernay et al., 1984) and corticosterone (Bonnafous and Raynaud, 1968; Kawakami et al., 1972) are doubled, it appears that the absorptive processes (Vernay et al., 1984; Vernay, 1987a,d), as well as the complete oxidation of butyrate and propionate, are enhanced in the colon but that they are invariably more extensive in the proximal than in the distal colon. Thus, the energy gained from the SCFA $\mathrm{S}_{\mathrm{S}}$ might be used for metabolic activities and cation transfer across the rabbit large intestine mucosa, as suggested for human (Roediger, 1980; Roediger and Moore, 1981; Cummings, 1984), rat (Roediger, 1982), guinea pig (Wirthensohn and von Engelhardt, 1981), and pig (Rérat et al., 1985) colon.

Intact SCFA and most labelled metabolites enter the portal blood. Thus, these nutrients have to pass through the liver before entering the general circulation. In our experimental conditions, the hepatic tissue of the rabbit appears to be an important site of acetate metabolism, as it removed $18-35 \%$ of the SCFA reaching it and practically all the labelled metabolites produced by the gut wall. Therefore, a part of the radioactive molecules recovered in hepatic homogenates were absorptive forms of the SCFA, since most of the metabolites that we attribute to colonocyte metabolism were recovered in the portal blood. This fact does not exclude a hepatic metabolism based on the acetate removed, but indicates the complexity of the metabolic pathways that led ${ }^{14} \mathrm{C}$ of SCFA from the gut lumen to the hepatocytes. The liver did not appear to accumulate glutamate to a great extent; it is possible that this amino acid is not stored but is rapidly utilized throughout the TCA cycle (Aikawa et al., 1972; Felig, 1973). The presence of an acetyl-CoA synthetase mainly located in the cytosol fraction (Woodnutt and Parker, 1978) indicates that in rabbit liver, as in rat liver (Hanson and Ballard, 1967; Knowles et al., 1974; Scholte and Groot, 1975), acetate was largely converted into fatty acids and carbon dioxide because the enzymes involved in fatty acid synthesis 


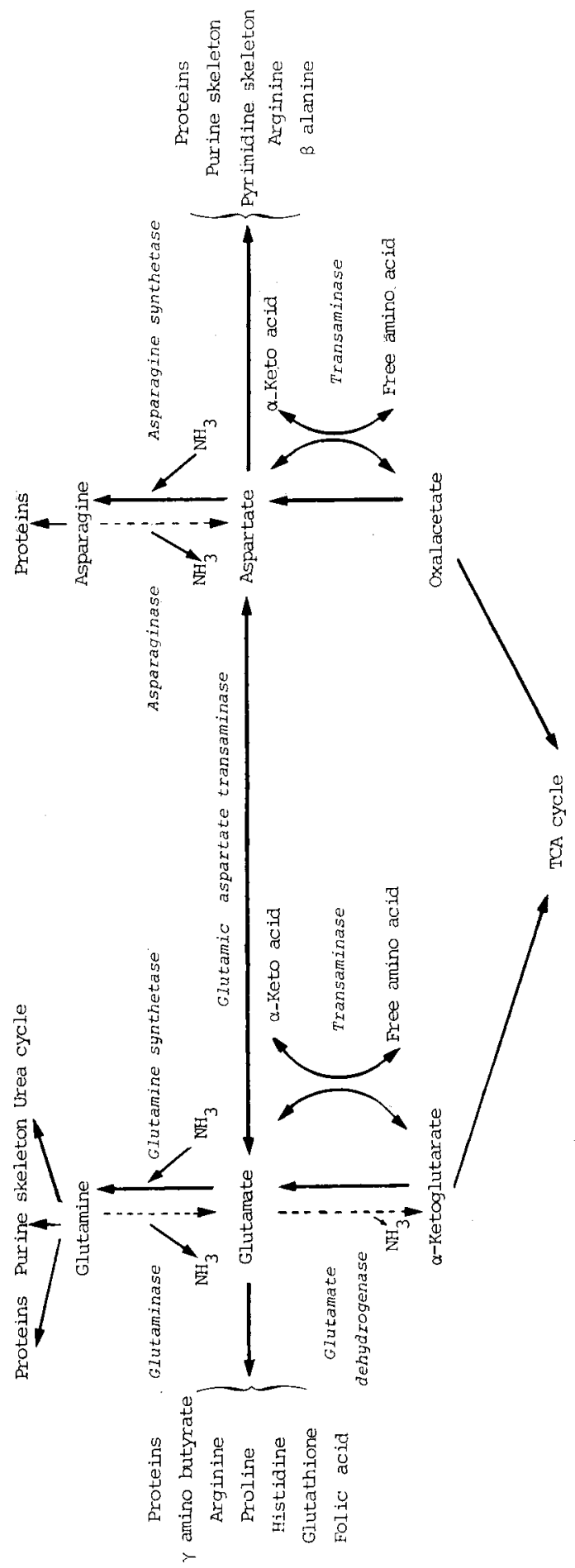

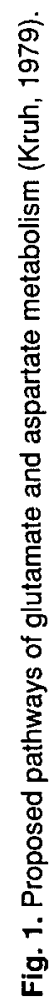


are cytosolic. Hepatic acetate metabolism increases with afferent blood concentrations in rats and rabbits (Buckley and Williamson, 1977; Rémésy et al., 1980; Vernay, 1985, 1986b); thus, irrespective of the mode of faecal excretion, the level of acetate in the hepatic vein was remarkably constant. It is interesting that in the general circulation this nutrient was the only SCFA present in significant concentrations (Beauville et al., 1974; McMillan et al., 1975; Bonnafous and Raynaud, 1978; Vernay, 1987a). In addition, there was no detectable labelling of free amino acids, showing that most of the labelled molecules entering the portal circulation were taken up by hepatocytes (Wolff and Bergman, 1972; Wolff et al., 1972). Nevertheless, a very slight radioactivity was found in glucose, lactate, and citrate which, like acetate, can be directly assimilated by peripheral tissues (Drury and Wick, 1956; Vézinhet and Nougut:s, 1977; Jones and Parker, 1977, 1981).

In conclusion, like propionate and butyrate (Vernay et al., 1984; Vernay, 1985, 1987b,c), acetate absorption and metabolism in the rabbit hind-gut varied with the segment studied and with the excretion pattern. During the hard-phase both mechanisms were enhanced in the proximal colon and to a lesser degree in the distal colon. The metabolic fate of the latter SCFA did not depend on the tissue that catabolized it or the phase of the excretory cycle, as is the case for the former SCFA. It appears that acetate is rapidly converted into glutamate and aspartate, then these amino acids can be diverted towards either oxidative metabolism or numerous biosyntheses (non essential free amino acids, proteins) according to colonocyte and hepatocyte requirements. Therefore, like propionate and butyrate, acetate is clearly an important nutrient for these cells.

\section{Acknowledgements}

Scintillation counting and analysis of amino acids, organic acids and sugars were done at the Centre de Physiologie Végétale, LA CNRS 241-UPS. The author wishes to thank Ms Marty and $\mathrm{Mr}$ Abravanel for their invaluable help and advice on the different techniques used.

\section{References}

Aikawa T., Matsutaka H., Takezawa K. \& Ishikawa E. (1972) Gluconeogenesis and amino acid metabolism. I. Comparison of various precursors for hepatic gluconeogenesis in vivo. Biochim. Biophys. Acta 279, 234-244

Argenzio R.A. \& Southworth M. (1974) Sites of organic acid production and absorption in the gastrointestinal tract of the pig. Am. J. Physiol. 228, 454-460

Ballard F.J., Hanson R.W. \& Kronfeld D.S. (1969) Gluconeogenesis and lipogenesis in tissues from ruminant and non-ruminant animals. Fed. Proc. 28, 218-231

Beauville M., Raynaud P. \& Vernay M. (1974) Concentration des acides gras volatils plasmatiques chez le lapin. Ann. Rech. Vét. 5 , 407-411

Bensadoun A., Paladines O.L. \& Reid J.T. (1962) Effect of level of intake and physical form of the diet on plasma glucose concentration and volatile fatty acid absorption in ruminants. J. Dairy Sci. 45, 1203-1210

Bergman E.N. \& Wolff J.E. (1971) Metabolism of volatile fatty acids by liver and portal-drained viscera in sheep. Am. J. Physiol. 221, 586-592

Buckley B.M. \& Williamson D.H. (1977) Origin of blood acetate in the rat. Biochem. J. 166, 539-545

Bonnafous R. \& Raynaud P. (1968) Possibilités d'une corrélation entre le taux plasmatique de corticostérone et le type d'excrétion fécale chez le lapin. Ann. Endocrinol. Fr. 29, 331-336

Bonnafous R. \& Raynaud P. (1978) Etude sur la concentration des AGV du matériel et des AGV et corps cétoniques plasmatiques au niveau des veines du gros intestin chez le lapin domestique. $2^{\circ}$ Journée Recherche Cunicole, Toulouse. Communication $n^{\circ} 5$. ASFC Paris

Clauss W. \& Hörnicke H. (1979a) Electrolyte absorption and secretion in the rabbit colon. 
Effect of the type of faeces and the time of the day. Gastroenterol. Clin. Biol. 3, 179A

Clauss W. \& Hörnicke H. (1979b) Circadian rhythm of electrical potential difference, plasma aldosterone and faecal $\mathrm{Na} / \mathrm{K}$-ratio in rabbits. Chronobiologia 2, 88A

Cook R.M. \& Miller L.D. (1965) Utilization of volatile fatty acids in ruminants. I. Removal of them from portal blood by the liver. J. Dairy Sci. 48, 1339-1345

Cummings J.H. (1984) Colonic absorption : the importance of short-chain fatty acids in man. Scand. J. Gastroenterol. 19, 89-99

Demigné C. \& Rémésy C. (1985) Stimulation of absorption of volatile fatty acids and minerals in the caecum of rats adapted to a very high fiber diet. J. Nutr. 115, 53-60

Dobson A. \& Phillipson A.T. (1956) Influence of the contents of the rumen and of adrenaline upon its blood supply. J. Physiol. 133, 76-77

Drury D.R. \& Wick A.N. (1956) Metabolism of lactic acid in the intact rabbit. Am. J. Physiol. 184, 304-308

Felig P. (1973) The glucose-alanine cycle. Metabolism 22, 179-207

Greenway G.V. \& Stark R.D. (1971) Hepatic vascular bed. Physiol. Rev. 51, 23-65

Hanson R.W. \& Ballard F.J. (1967) The relative significance of acetate and glucose as precursors for lipid synthesis in liver and adipose tissue trom ruminants. Biochem. $J$. 105, 529-536

Henning S.J. \& Hird F.J.R. (1972a) Diurnal variations in the concentration of volatile fatty acids in the alimentary tract of wild rabbits. $\mathrm{Br}$. J. Nutr. 27, 57-64

Henning S.J. \& Hird F.J.R. (1972b) Ketogenesis from butyrate and acetate by the caecum and the colon of rabbits. Biochem. J. $130,785-790$

Henning S.J. \& Hird F.J. (1972c) Transport of acetate and butyrate in the hind-gut of rabbits. Biochem. J. 130, 791-796

Holdsworth E.S., Neville E., Nader C., Jarrett I.G. \& Filsell O.H. (1964) The metabolism of acetate in the sheep. Biochim. Biophys. Acta $86,240-249$

Hoover W.H. \& Heitmann R.N. (1972) Effects of dietary fiber levels on weight gain; cecal volume and volatile fatty acids production in rabbits. J. Nutr. 102, 375-380

Hörnicke H. \& Björnhag C. (1980) Coprophagy and related strategies for digesta utilization. In: Digestive Physiology and Metabolism in
Ruminants (Y. Ruckebusch and P. Thivend, eds.), MTP Press Ltd., Lancaster, pp. 707-730

Hyden S. (1956) A turbidometric method for the determination of higher polyethylene glycols in biological materials. Lantbrukshögsk Ann. 22, 139-145

Jones C.S. \& Parker D.S. (1977) Arteriovenous difference studies on the lactating rabbit mammary gland. Proc. Nutr. Soc. 26, 2A

Jones C.S. \& Parker D.S. (1981) The metabolism of glucose, acetate and palmitate in the lactating rabbit. Comp. Biochem. Physiol. 69B, 837-842

Kawakami M., Seto K. \& Kimura F. (1972) Influence of repeated immobilization stress upon the circadian thythmicity of adrenocorticoid biosynthesis. Neuroendocrinology 9 , 207-214

Knowles S.E., Jarrett I.G., Filsell O.H. \& Ballard F.J. (1974) Production and utilization of acetate in mammals. Biochem. J. 142, 401-411

Kruh J. (1979) Diacides aminés et acides aminés amides, In : Biochimie études médicales et biologiques. II. Métabolismes (J. Kruh, ed.). Hermann, Paris, pp. 162-163

Kvietys P.R. \& Granger D.N. (1981) Effect of volatile fatty acids on blood flow and oxygen uptake by the dog colon. Gastroenterology 80 , 962-969

Lavergne D., Bismuth E. \& Champigny M.L. (1979) Physiological studies on two cultivars of Pennisetum : $P$. americanum 23 DB a cultivated species and $P$. mollissimum a wild species. 1. Photosynthetic carbon metabolism. Z. Pflanzenphysiol. Belg. 91, 291-303

Leng E. (1978) Absorption of inorganic ions and volatile fatty acids in the rabbit caecum. Br. J. Nutr. 40, 509-519

Leung T.T. \& Bauman D.E. (1975) In vivo studies of the site of fatty acid synthesis in the rabbit. Int. J. Biochem. 6, 801-805

Marty J. \& Vernay M. (1984) Absorption and metabolism of the volatile fatty acids in the rabbit hindgut. Br. J. Nutr. 51, 265-277

Mayfield E.D., Bensadoun A. \& Johnson B.C. (1966) Acetate metabolism in ruminant tissues. J. Nutr. 89, 189-196

McMillan R.T., Edwards N.A. \& Parker D.S. (1975) Observations on the volatile fatty acids present in the hind-gut and in the blood of the domestic rabbit. Proc. Nutr. Soc. 34, 21A-22A

Parker D.S. (1976) The measurement of production rates of volatile fatty acids in the 
caecum of the conscious rabbit. Br. J. Nutr. 36 , 61-78

Pethick D.W., Lindsay D.B., Barker P.J. \& Northrop A.J. (1981) Acetate supply and utilization by the tissues of sheep in vivo. Br. J. Nutr. 46, 97-110

Rémésy C. \& Demigné C. (1974) Determination of volatile fatty acids in plasma after ethanolic extraction. Biochem. J. 141, 85-91

Rémésy C. \& Demigné C. (1976) Partition and absorption of volatile fatty acids in the alimentary canal of the rat. Ann. Rech. Vét. 7, 39-55

Rémésy C., Demigné C. \& Chartier F. (1980) Origin and utilization of volatile fatty acids in the rat. Reprod. Nutr. Dév. 20, 1339-1349

Rémésy C. \& Demigné C. (1982) Impaired lactate utilization in livers of rats fed high protein diets. J. Nutr. 112, 60-69

Rérat A., Fiszlewicz M., Herpin P., Vaugelade P. \& Durand M. (1985) Mesure de l'apparition dans la veine porte des acides gras volatils formés au cours de la digestion chez le porc éveillé. C.R. Acad. Sci. Paris 300, 467-470

Roediger W.E.W. (1980) Role of anaerobic bacteria in the metabolic welfare of the colonic mucosa in man. Gut 21, 793-798

Roediger W.E.W. (1982) Utilization of nutrients by isolated epithelial cells of the rat colon. Gastroenterology 83, 424-429

Roediger W.E.W. \& Moore A. (1981) Effect of short-chain fatty acids on sodium absorption in isolated human colon perfused through the vascular bed. Am. J. Dig. Dis. 26, 100-106

Scholte H.R. \& Groot P.H.E. (1975) Organ and intracellular localization of short-chain acylCoA synthetase in rat and guinea pig. Biochim. Biophys. Acta 409, 283-296

Schurmann P. (1969) Separation of phosphate esters and algal extracts by thin-layer electrophoresis and chromatography. $J$. Chromatrogr. 39, 507-509

Sellers A.F. (1965) In : Physiology of Digestion in the Ruminant (R.W. Dougherty, ed.), Butterworths, London, pp. 171-184

Snipes R.L., Clauss W., Weber A. \& Hörnicke H. (1982) Structural and functional differences in various divisions of the rabbit colon. Cell Tissue Res. 225, 331-346

Vernay M. (1985) L'absorption et le devenir des acides gras volatils digestifs chez le lapin, en relation avec la dualité de l'émission fécale. Th. Doct. Etat, Univ. Paul-Sabatier, Toulouse III
Vernay M. (1986a) Colonic absorption of inorganic ions and volatile fatty acids in the rabbit. Comp. Biochem. Physiol. 83A, 775-784

Vernay M. (1986b) Influence de la caecotrophie sur la production, l'absorption et l'utilisation des acides organiques chez le lapin. Reprod. Nutr. Dév. 26, 1137-1149

Vernay M. (1987a) Origin and utilization of volatile fatty acids and lactate in the rabbit : influence of the faecal excretion pattern. Br. $J$. Nutr. 57, 371-381

Vernay M. (1987b) Propionate absorption and metabolism in the rabbit hind-gut. Gut 28, 1077-1083

Vernay M. (1987c) Effects of plasma aldosterone on butyrate absorption and metabolism in the rabbit proximal colon. Comp. Biochem. Physiol. 86A, 657-662

Vernay M. (1987d) Volatile fatty acid absorption across rabbit colon in vivo. Dtsch. Tieräztl. Wschr. 94, 7-12

Vernay M. \& Marty J. (1984) Absorption and metabolism of butyric acid in rabbit hind-gut. Comp. Biochem. Physiol. 77A, 89-96

Vernay M., Marty J. \& Moatti J.P. (1984) Absorption of electrolytes and volatile fatty acids in the hind-gut of the rabbit. Circadian rhythm of hind-gut electrolytes and plasma aldosterone. Br. J. Nutr. 52, 419-428

Vernay M. \& Raynaud P. (1975) Répartition des acides gras volatils dans le tube digestif du lapin domestique. Ann. Rech. Vét. 6, 357-377

Vézinhet A. \& Nouguès J. (1977) Postnatal evolution of lipogenesis in adipose tissue and liver of lamb and rabbit. Ann. Biol. Anim. Biochim. Biophys. 17, 851-863

Wolff J.E., Bergman E.N. \& Williams H.H. (1972) Net metabolism of plasma amino acids by liver and portal-drained viscera of fed sheep. Am. J. Physiol. 223, 438-446

Wolff J.E. \& Bergman E.N. (1972) Metabolism and interconversions of five plasma amino acids by tissues of the sheep. Am. J. Physiol. $223,447.454$

Wirthensohn K. \& von Engelhardt W. (1981) Uptake of sodium and short-chain fatty acids into colonic epithelial cells. Gastroenterol. Clin. Biol. 5, 125A

Woodnutt G. \& Parker D.S. (1978) Rabbit liver acetyl-CoA synthetase. Biochem. J. 175, 757759 